\title{
Exploration and Practice of Undergraduate Classroom Teaching Reform Centered on Student Development
}

\author{
Xiaoyan Li* \\ Department of Public Teaching, Qilu Medical University, Zibo 255000, Shandong Province, China
}

\begin{abstract}
The reform of undergraduate classroom teaching is well underway along with the continuous development of education reform in China. In regard to that, lecturers must promptly innovate teaching concepts and reform undergraduate classroom teachings with emphasis on student development so as to create a first-class teaching classroom experience and effectively address shortcomings in the undergraduate classroom teaching model. The improvement and optimization of teaching concepts fully reflect the main status of students. In this paper, the problems existing in the undergraduate classroom teaching are explored and analysed. A practical strategy for undergraduate classroom teaching reform centered on student development is proposed, hoping to help in students' overall development.
\end{abstract}

Keywords: Student development; Undergraduate classroom; Education reform; Practice strategy

Publication date: May, 2021; Publication online: 31 May, 2021

*Corresponding author: Xiaoyan Li, lily_sdnu@126.com

\section{Introduction}

Currently, there are various problems in the undergraduate classroom teaching, which not only affect the smooth progress of classroom teaching activities but also, the development of students to a certain extent. Hence, lecturers must actively explore the reform of undergraduate classroom teaching and encourage its' practice to ensure that the development of undergraduate classroom teaching activities addresses the students' needs in addition to nurturing talents for social growth.

\section{Student Development-Centered Education}

Student development-centered education is an educational philosophy that lecturers of all disciplines need to adhere to after the implementation of China's education reform. ${ }^{[1]}$ In the process of conducting educational and teaching activities, undergraduate colleges and universities need to innovate and reform undergraduate classroom teaching under the guidance of this educational philosophy. The definition of student development-centered education mainly includes two aspects, which are the narrow and broad aspects, as shown in Table 1.

\section{Problems in Undergraduate Classroom Teaching}

\subsection{Existing problems in students}

In the process of reforming undergraduate classroom teaching activities centered on student development, it is necessary to fully reflect the main status of students as well as to focus and value students' learning and development. ${ }^{[3]}$ However, judging from the current situation of undergraduate classroom teaching, the performance of students is not very satisfactory. See Table 2 for details. 
Table 1. Definition of student development-centered education

\section{Definition of student development-centered education}

Narrow aspect

Broad aspect

\section{Content}

A way or method used by lecturers when conducting educational and teaching activities by emphasizing only on learning outcomes and the development of students. ${ }^{[2]}$

In the process of conducting education and teaching activities, lecturers need to consider the healthy growth and overall development of students as the focus of education and teaching, thus educating high school students to become qualified talents that addresses the needs of social development.

Table 2. Students' bad conducts in undergraduate classroom teaching

\section{Students' bad conducts in undergraduate classroom teaching}

Late arrival, early departure and absenteeism

Improper learning attitude

Too addicted to mobile phones

\section{Specific content}

(1) During high school, students are often instilled with the idea that "it is the last three years of hard work, and they will be liberated once they commence tertiary education." This idea is the reason for being late to class, leaving earlier, and absenteeism once many students pursue higher education.

(2) Classroom teaching time is already fairly limited, in addition to relatively heavy teaching and education tasks. Therefore, it is difficult for lecturers to supervise and manage the attendance of students in every class in regard to absenteeism. Eventually, teachers have difficulty in making timely and accurate responses.

(1) Students that play poker at the back of the class emulate those who are sitting in the middle; what they do is sleeping, which do not disturb learning activities of the class. During undergraduate classroom teachings, students often do things that have no relation with learning. This greatly affects the undergraduate classroom teaching.

(2) Some students sleep late at night, or even play online games all night long. They suffer from severe sleep deprivation; hence, they often compensate by sleeping during classroom sessions. In turn, the classroom is regarded as a place for sleep and rest.

(1) Nowadays, almost every undergraduate student has a smartphone. According to related surveys, in a lesson of 45 minutes, more than half of the students play games, but there are variations in the duration of playing time. Of course, there are also cases where they are playing with mobile phones the whole time.

(2) Although some lecturers will instruct students to place their mobile phones in their bags before lessons, many students bring two mobile phones to classes, so that there is a spare phone to play with. As the saying goes, "for every policy from the top, there is countermeasure at the bottom." 


\subsection{Existing problems in lecturers}

When reforming undergraduate classroom teaching centered on student development, lecturers should place importance to the role as guides and instructors, adhere to the student developmentcentered teaching concept, and explore the content of undergraduate classroom teaching in-depth. ${ }^{[4]}$ However, judging from the actual situation of undergraduate classroom teaching currently, there are still two problems to be solved on the lecturers' side, as shown in Table 3.

Table 3. Lecturers' problems in undergraduate classroom teaching

\begin{tabular}{ll}
\hline Problems & Main Content \\
\hline & (1) Some lecturers only see undergraduate classroom teaching as a task to \\
be completed and not as a career. \\
(2) Lecturers treat completion of teaching tasks with assured quality and \\
Teaching regarded as a & (3) They may neglect students' understanding and mastery of knowledge. \\
task to be completed & (4) Too much emphasis is placed on the teaching of theoretical knowledge \\
& and practical skills, and ethical aspects are largely neglected.
\end{tabular}

(1) Although it is recognized that the application of internet technology in the field of education can improve teaching quality and has been widely promoted, ${ }^{[6]}$ there are still lecturers who have limited mastery of

Lack of utilization of information technologies information technology and rarely apply this skill or relevant tools in their lessons.

(2) Some lecturers have strengthened the use of information technology in classroom teaching, but they only use multimedia equipment for presentation, and the content of the courseware is mostly copied from the textbook. ${ }^{[7]}$

\section{Practical Strategies for Undergraduate} Classroom Teaching Reform Centered on Student Development

\subsection{Careful design of the undergraduate classroom teaching reform plan}

In the process of reforming undergraduate classroom teaching centered on student development, we must carefully design a teaching reform plan to greatly improve the quality of teaching. There are many shortcomings in the traditional undergraduate classroom teaching. If lecturers are only superficial when carrying out classroom teaching reform, they will still dominate the entire teaching session. Hence, they are unable to fully cultivate students' learning initiative and students will still lack the motivation to learn. This shows that careful design of undergraduate classroom teaching reform plan is particularly important. ${ }^{[8]}$ For example, in an undergraduate college, the training of the teaching staffs was first carried out in the process of implementing undergraduate classroom teaching reform centered on student development. This helped standardize and improve the standards of professors and associate professors, and the quality of teaching was significantly improved. Secondly, the college has established a complete teaching system for professors and associate professors, whereby almost all undergraduate students were taught by professors or associate professors. Thirdly, in order to prompt the professors to change their goals from only completing teaching tasks to achieving the transformation of teaching tasks, and further deepen the reform of undergraduate classroom teaching, the undergraduate college has developed a unique demonstration classroom plan centered on 
student development. Its purpose is to create an open classroom with more involvement of the students. Finally, after completing the construction of the open teaching model, the undergraduate college has also carried out a scientific and reasonable reform of teaching assessment, further highlighting the main status of students, and fully cultivating students for independent thinking and learning. In the process of carefully designing the undergraduate classroom teaching reform plan, we must emphasize on the nurturing of students' independent learning, innovation, and thinking skills as the main teaching tasks, in addition to motivate students so that they proactively participate in classroom teaching, thereby increasing interactions among students and improving teaching quality, which are the main purpose of undergraduate classroom teaching reform.

\subsection{Building of an open and high-quality demonstration classroom by means of project establishment}

The effect of undergraduate classroom teaching reform directly affects the training of talents and the development of colleges. Therefore, in the process of reforming undergraduate classroom teaching, the student development-centered education philosophy must be observed throughout the classroom teaching reform. The development of various reforms must be in adherence to this education philosophy. In the process of implementing undergraduate teaching reform, it is not only necessary to ensure the smooth implementation of teaching reform, but also to secure the outcome of teaching reform, establish excellent demonstration classrooms, increase the efforts in its promotion and application, and strive to establish a double first-class undergraduate classroom teaching mode. ${ }^{[9]}$ For example, an undergraduate college that is exploring and implementing student development-centered undergraduate classroom teaching reform is building an open, high-quality demonstration classroom every year by means of project establishment. In this process, undergraduate schools should adhere to the basic principles of gradual and orderly progress, "snow-mountain style linearity," and strive to create a double firstclass undergraduate teaching environment to encourage students to obtain greater benefits. As the leaders of undergraduate colleges and universities, more attention should be paid to the establishment of projects. On the other hand, the vice presidents should focus on the high-quality demonstration open classrooms to guide education and teaching activities. The person in-charge of teaching support at an undergraduate college should provide lecturers with the necessary software and hardware according to the teaching content and ensure that there is sufficient infrastructure as well as financial support in the process of implementing the undergraduate classroom teaching reform through project establishment.

\subsection{Gradual assessment and adoption of the} outcomes of undergraduate classroom teaching reforms and creation of corresponding assessment index systems

After completing the establishment of high-quality demonstration courses for student developmentcentered undergraduate classroom teaching reform, undergraduate colleges and universities need to carry out gradual trial and adoption, and make them the main research subjects for exploration and implementation of undergraduate classroom reforms in order to achieve the desired effects of the reform. ${ }^{[10]}$ The design of classroom teaching content, the choice of teaching methods, and the creation of the teaching assessment system all have a certain link with the student developmentcentered undergraduate classroom teaching reform. Therefore, in the process of trial and adoption of the teaching reform outcomes, the relationships between these factors must be solved. For example, in the process of gradual adoption of the outcomes of undergraduate classroom teaching reform, an undergraduate college created the "Student Development-Centered Quality Demonstration Classroom Teaching Reform Requirements and Assessment Index System," which involves multiple indicators, such as teaching concepts, quality of the teaching staffs, lecture design, teaching methods and impacts, as well as multiple secondary assessment indicators. When gradually adopting the outcomes of undergraduate classroom teaching reform, firstly, it is necessary to check 
whether the student development-centered teaching concept is fully implemented, and secondly, it is necessary to check on the cultivation of students in self-learning, and the fostering of thinking skills, innovation ability, entrepreneurship, and employability. All in all, the direction and outcomes of undergraduate classroom teaching reform must be consistent with the student development-centered education philosophy.

\section{Conclusion}

In conclusion, in the process of exploring and implementing undergraduate classroom teaching reform centered on student development, we must fully and correctly recognize the current problems in undergraduate classroom teaching. Only in this way, we can better carry out teaching reform to nurture more outstanding talents.

\section{Disclosure statement}

No conflicts of interest.

\section{References}

[1] Liu, J., Fang, Y., Zuo W(2020). Research on the Influence of Mobile Internet on the Reform of Teaching Mode in Undergraduate Colleges. Education and Teaching Forum, (34):155-156.

[2] Yang, B., Xu, F., Zhou, C(2020). Classroom Teaching Method Reform is the Key to Innovative Education. Physics and Engineering, 30(04):42-47. [3] Tang, J., Wu, Y., Jiang, Z(2020). The Construction and Practice of Undergraduate Talent Training Program in Local Universities under the Background of the New Four Subjects--Taking
Xihua University as an Example. Journal of Higher Education, (24):151-154.

[4] Lu, S., Liu, C., Li, X., Zhu, H., Luo, W., Liang, M(2020). A Preliminary Study on the Teaching Reform to Improve the Quality of StudentCentered Courses: Taking the Course of "Semiconductor Physics and Devices" as an Example. Journal of Higher Education, (21):143146.

[5]Hong, Y., Xie, D(2020). The Organizational Autonomy of Undergraduate Teaching Reform in China: Ideal State and Realistic Deviation. Zhejiang Social Sciences, (07):136-141,150,161.

[6]Zheng, R.(2020). Research on English Teaching Reform in Applied Undergraduate Colleges under the Background of "Double First Class" Construction. PR Magazine, (07):57-58.

[7] Shi, J(2020). Research on Teaching Reform of Applied Undergraduate Courses in the Internet Era-Taking "E-commerce Case Analysis" Course as an Example. Education and Teaching Forum, (28):173-174.

[8] Shi, M., Pan, S., Li, Y., Song, J(2020). Research on the Reform of Teaching Methods in Undergraduate Colleges under Hybrid Teaching Mode. Education Modernization, 7(44):66-68.

[9] Du, W., Li, A., Wu, B(2020). Student-Centered and Project-Oriented Teaching Reform and Practice: Taking New Energy Technology and Application Courses as Examples. Higher Education in Chemical Engineering, 37(02):97-102. [10]Wu, D., Shen, Z(2020). Rational Thinking on the Development of Online Teaching in Chinese Universities Based on the Empirical Investigation of 6 Undergraduate Universities. Education Science, 36(02):1-8. 